\title{
The Determinants of Returns on China-Concept Stocks Listed in Taiwan Stock Market
}

\author{
Chau-Chen Yang \\ National Taiwan University \\ yang@mba.ntu.edu.tw \\ Cheng-Few Lee \\ Rutgers University \\ Chung-Jiun Lin \\ National Taiwan University \\ Ya-Ting Chung \\ Sinopack Bank
}

We use a probit selection model to investigate whether the relation between stock returns and their fundamental determinants varies for China-concept and nonChina-concept stocks. In addition, an ordered probit selection model is used as well to explore whether the determinants of stock returns change due to the different level of investments in China. There are a lot of reasons for Taiwanese firms to invest in China. The stock of a firm with capital investments in China is called China-concept stock. A firm can decide whether to go for its capital investments in China or not. It is interesting to investigate whether a firm's decision to invest in China affects the determination of stock returns or not. This investment decision should not be treated as exogenous in examining the determinants of stock returns. Hence, a two-stage selection model is employed for this purpose. We find that heavy-level-investment-in-China firms do exhibit a different relation between stock returns and their fundamental determinants. Book-to-market ratio is the most important determinant of stock returns for all firms.

Keywords: China-concept stocks; probit selection model; real investments; book-to-market ratio. 


\section{Introduction}

This paper is among the few researches attempting to link firms' capital investment decisions and stock return determinants together. As is well known in finance literature, investment decision is one of the three major decisions of a firm. According to finance theory, in a perfect world, investment decision is the only decision that may change the value of a firm. Financing and dividend decisions should not affect the value of a firm. In an imperfect world, all of these three decisions may affect the value of a firm. However, investment decision is the most important of the three in creating value for a firm. Through investments in positive NPV projects, a firm's market value is then raised. Hence, an investment decision will undoubtedly affect a firm's stock returns.

The specific investment decision examined in this paper is Taiwanese firms' real investments in mainland China. In the past ten years, China has provided much cheaper labor and land costs than most other countries in Asia, at only one tenth of those in Taiwan. The profits of these investments have contributed a nontrivial percentage to the earnings of their parent companies in Taiwan. In this paper we treat this investment decision as an endogenous decision rather than an exogenous situation and are interested in examining whether the real investment decisions of firms affect the relation between their stock returns and fundamental determinants. A two stage Probit selection model is employed to do this research. In the first stage, a probit model is used to predict which firms will have real investments in the mainland China, while in the second stage, conditional regressions are done to examine the relation between stock returns and their fundamental determinants. Then, we compare whether this relation are different for firms with investments in China and without.

\section{Real Investments in China}

China has always been the focus of the world. It has the largest population in the world, 1.3 billion people. In other words, there exits huge business opportunities for foreign companies. Furthermore, with its cheap labor and land costs, China attracts tens of thousands foreign companies to set up plants as production bases. Companies in Taiwan have been eager to build manufacturing plants in the mainland China. A major percentage of them are listed firms in the Taiwan Stock Exchange. The stocks of listed firms in Taiwan with real investments in the mainland China are thus often called "China-concept" stocks. Many companies take orders in Taiwan, but 
manufacture goods in the mainland China. Low costs of goods produced in China contribute a great percentage of earnings to China-concept stocks listed in Taiwan.

The accumulated trades between Taiwan and China reaches 190.9 billion US dollars, with a trade deficit of 128.9 billion for China, by the end of 2000 . In 2000 alone, Taiwan's exports to China amount to 25.5 billion dollars, while imports from China are only 5 billion dollars. Currently, Taiwan is China's number five biggest trading partner, while China is Taiwan's number two biggest exporting country and number one greatest trading surplus country. Based on the aforementioned information, it is apparent how close is the relationship between Taiwan and China in terms of business and economy. It is also apparent why China-concept stocks play important roles in the Taiwan stock exchange.

Ever since the relaxation of Taiwan legislation that permits people to visit relatives in China, the investment and business opportunities have been uncovered and explored. Meanwhile, due to the increase of labor costs and land price, plus social awareness of environmental concerns, the investment condition in Taiwan has become less attractive and less profitable for those so-called "sunset industries". Hence they were forced to leave for other countries where competitiveness could be restored and profit margin could be widen. The geographical and cultural advantages of China, its abundant natural resource and the economic policy that designed to attract overseas capital and technology provide irresistible attraction to companies facing down sizing crisis in Taiwan. As shown in Table 1, according to the statistics released by ICMEA, the annual amounts for Taiwan companies invest in China are very huge although deviate a lot in size from the beginning till now. Total investments in China by Taiwanese firms permitted by ICMEA from 1991 to 2000 amount to 17 billion US dollars. However, according to the data released by China's International Economy and Trade Ministry, the numbers are 47.2 and 25.6 billion US dollars respectively for the amount approved by China government and for the amount actually invested. ${ }^{1}$ The real investments in China by Taiwanese listed firms in this period is 4 billion dollars, according to ICMEA, which is about $23.5 \%$ of the investments by total firms in the same period.

Due to the good performance for investments in China in terms of EPS, the China-concept stocks have become more popular in Taiwan Stock Market

\footnotetext{
${ }^{1}$ The statistics released by China for year 2000 includes only the investments from January to September, 2000, while that released by ICMEA is updated to the end of 2000.
} 
Chau-Chen Yang et al.

Table 1. Investments in China by Taiwanese firms as permitted by ICMEA.

\begin{tabular}{|c|c|c|c|c|c|c|}
\hline \multirow[b]{2}{*}{ Year } & \multicolumn{3}{|c|}{$\begin{array}{l}\text { Total Investments in } \\
\text { China Permitted by } \\
\text { ICMEA - All Firms }\end{array}$} & \multicolumn{3}{|c|}{$\begin{array}{c}\text { Total Investments in } \\
\text { China Permitted by } \\
\text { ICMEA - Only Listed Firms }\end{array}$} \\
\hline & $\begin{array}{l}\text { Number of } \\
\text { Cases }\end{array}$ & $\begin{array}{c}\text { Total } \\
\text { Investments }\end{array}$ & $\begin{array}{c}\text { Average } \\
\text { Investments }\end{array}$ & $\begin{array}{l}\text { Number } \\
\text { of Cases }\end{array}$ & $\begin{array}{c}\text { Total } \\
\text { Investments }\end{array}$ & $\begin{array}{c}\text { Average } \\
\text { Investments }\end{array}$ \\
\hline 1991 & 237 & 174.16 & 0.73 & 16 & 40.72 & 2.54 \\
\hline 1992 & 264 & 246.99 & 0.94 & 28 & 76.27 & 2.72 \\
\hline 1993 & 1,262 & $1,140.36$ & 0.90 & 111 & 405.55 & 3.65 \\
\hline & 8,067 & $2,028.05$ & 0.25 & & & \\
\hline 1994 & 934 & 962.21 & 1.03 & 48 & 202.30 & 4.21 \\
\hline 1995 & 490 & $1,092.71$ & 2.23 & 57 & 274.20 & 4.81 \\
\hline 1996 & 383 & $1,229.24$ & 3.21 & 85 & 439.71 & 5.17 \\
\hline 1997 & 728 & $1,614.54$ & 2.22 & 117 & 627.53 & 5.36 \\
\hline & 7,997 & $2,719.77$ & 0.34 & & & \\
\hline 1998 & $\begin{array}{l}641 \\
643\end{array}$ & $\begin{array}{r}1,519.21 \\
515.41\end{array}$ & $\begin{array}{l}2.37 \\
0.80\end{array}$ & 68 & 442.20 & 6.50 \\
\hline 1999 & 488 & $1,252.78$ & 2.57 & 77 & 310.50 & 4.03 \\
\hline 2000 & 840 & $2,607.14$ & 3.10 & 162 & $1,013.82$ & 6.25 \\
\hline $\begin{array}{l}2001 \\
\text { (Jan-March) }\end{array}$ & 152 & 563.85 & 3.70 & 39 & 171.77 & 4.40 \\
\hline Total & 23,126 & $17,666.42$ & 1.74 & 808 & $4,004.55$ & 4.51 \\
\hline
\end{tabular}

* Statistics are provided by ICMEA; unit: Million dollars.

than ever. However, investments in China by Taiwanese firms have been expanding too fast and too much in scale to control, Taiwan's government has adopt ways to let these Taiwanese firms cool down in recent years.

Though there are cost advantages for these China-concept companies, the prices of their shares fluctuate around news related to the relationship between both sides of the Taiwan Straits. When the relationship is good, the China-concept stocks tend to go up, and when bad, tend to go down.

Previous studies have not quite kept pace with the rising of the aforementioned events. There is very limited and comparable evidence of the impact on Taiwan stock market by the China-investment behavior of firms. Hence, this paper intends to investigate if the investment in China of a listed company will cause any change in the relation between stock returns and common risk factors.

\section{Determinants of Stock Returns}

For both academics and practitioners, how to identify factors that best capture the systematic components of stock return variation is deemed as 
the most crucial issue. As a result, it has been a long history of exploring variation in stock returns by fundamental analysis. In US, the crosssectional relationship between stock returns and fundamental variables has attracted a considerable amount of research attention and been extensively studied. Among the frequently cited fundamental variables are size, $\mathrm{P} / \mathrm{E}$, Book/Market, and cash flow ratio.

Stattman (1980) and Rosenberg, Reid, and Lanstein (1985) provide earlier evidence of an important book-to-market value $(\mathrm{B} / \mathrm{M})$ effect by showing that average returns on US stocks are positively related to the ratio of a firm's book value of common equity to its market value. Chen, Hamao, and Lakonishok (1991) find that book-to-market ratio B/M, also has a strong role in explaining the cross-section of average returns on Japanese stocks. Fama and French (1992) report that stocks with high book-to-market ratios have reliably higher returns than lower book-to-market stocks of the same size. Capapl, Rowley, and Sharpe (1993) find evidence of a B/M effect in each of the major stock markets (United States, Japan, Germany, the United Kingdom, France, and Switzerland). They conclude that, during their study period (January 1981 through June 1992), portfolios of high-B/M stocks provided risk-adjusted returns superior to those from low-B/M stocks. They point out that the merit of $\mathrm{B} / \mathrm{M}$ as a single variable to distinguish between value and growth stock. Chen, Hamao, and Lakonishok (1991) design a modified Seemingly Unrelated Regression Model to find out that cash slow has a significant forecast power for expected returns on Japanese stocks. Moreover, before model adjustment, cash follow and $\mathrm{B} / \mathrm{M}$ ratio have positive relation with stock returns; after model adjustment, these two variables still have most powerful explanatory power on the stock returns. Chen, Karceski and Lakonishok (1998) evaluate the performance of various proposed factors in capturing return co-movements. The empirical results of this most updated study show that factors associated with the market, size, past return, bookto-market and dividend yield help explain return co-movement on an outof-sample basis.

Academic research has a long history of finding the relation between fundamental factors and stock returns. However, there is limited research focusing on the China-concept stocks listed in Taiwan stock market. Due to the close economic and political relationship between Taiwan and China, we have strong believe that the relationship between stock returns and their fundamental determinants may differ between China-concept and non-Chinaconcept stocks listed in Taiwan stock markets. Hence, the objective of this study is to examine empiricaly the impact of real-investment-in-China on 
the relation between stock returns and market fundamentals of stocks in Taiwan. A Two-Stage Selection Model is employed in this study. The results provide much valuable information for the decision making of corporate and investors.

In recent years, money managers in the US, as well as in other countries, have substantially increased their exposure to the Taiwan market. In spite of the rapid growth of investment in China from Taiwan company and the increasing significance of impact to the parent company and Taiwan stock market, only little researchers turned their attention to this.

This paper remedies the lack of substantive evidence on the relation between stock return and fundamental variables for China-concept stocks in Taiwan. The results provide some insights into much needed information on which fundamental factors (if any) are at work in the Taiwan stock market, especially for China-concept stocks. Evidence from this paper is expected to be helpful to shed further light on whether one fundamental variable subsumes another and on whether the results are robust to time period and sample composition. The accounting ratios reported here are suggestive but not exhaustive indicators for finding the differences between China-concept stocks and non-China-concept stocks. It suggests that there are other indicators that can better capture the market and management's expectation of the uncertainty faced by China-concept stocks. On the other hand, finding that different factors are at work in the different categories of company would suggest further research exploring institutional or behavioral differences between them.

\section{Data}

We use a comprehensive, high-quality data set of Taiwan stock market and the relevant information for investment in China extending over a relatively long period of time. Financial data are retrieved from the database of Taiwan Economic Journal (TEJ), with sampling period from 1993 to $1999 .^{2}$ Statistics of real investments in mainland China as permitted by ICMEA are provided by ICMEA. Financial institutions and financial distress firms are excluded from the sample. All companies must be listed in Taiwan Stock Exchange before 1993. Besides, to complete the possible missing information, a direct inquiry is made to investment department of company if necessary.

\footnotetext{
${ }^{2}$ Due to the fact that the majority of investments in China were made by small or medium size companies before 1993, we decides to discard the data before 1993 in order to avoid selection bias.
} 
Table 2. Sample size - 2-groups-classification. Company that has no approved China-investment by ICMEA is set to be "0" and named as non-China-concept stock. On the other hand, company with approved China-investment is set to be "1" and named as China-concept stock.

\begin{tabular}{lrrrrrr}
\hline & 1993 & 1994 & 1995 & 1996 & 1997 & 1998 \\
\hline 0 & 141 & 155 & 169 & 180 & 188 & 212 \\
1 & 40 & 62 & 76 & 92 & 110 & 127 \\
Total & 181 & 217 & 245 & 272 & 298 & 339 \\
\hline
\end{tabular}

Table 3. Sample size - 3-groups-classification. Company that has no approved China-investment by ICMEA is set to be "0" and named as non-China-concept stock. For China-concept stock, company with approved China-investment amount less or large than the average of total China-investment amount is set to be "1" or "2" and named as moderate level China-concept stock or heavy-level China-concept stock respectively.

\begin{tabular}{lrrrrrr}
\hline & 1993 & 1994 & 1995 & 1996 & 1997 & 1998 \\
\hline 0 & 141 & 155 & 169 & 180 & 188 & 212 \\
1 & 28 & 40 & 48 & 60 & 72 & 82 \\
2 & 12 & 22 & 28 & 32 & 38 & 45 \\
Total & 181 & 217 & 245 & 272 & 298 & 339 \\
\hline
\end{tabular}

During period $t$, observations are classified according to the total Chinainvestment amount accumulated till period $t-1$. A stock is classified as a China-concept stock at $t$ period if the issuing firm had investments in China prior to $t$ period. The sample size of each period is shown in Tables 2 and 3.

\section{Econometric Models}

In addition to a Probit Selection Model, an Ordered Probit Selection Model is employed in this paper. There are two stages for this econometric model too. At the first stage, an ordered probit model is run to explore the impacts of independent variables on the ordered dependent variables. Then, in the second stage, a conditional OLS is run for each category.

There are multinomial-choices variables that are inherently ordered, such as the following examples mentioned in Greene (1993):

1. Bond ratings.

2. Results of taste tests.

3. opinion surveys. 
The order in our paper is related to the level of Taiwanese firms' investment in the Mainland China. The probit model is a special case of the ordered probit model with the number of categories being two. We use three categories for the ordered probit model in this paper.

The ordered probit selection model can be expresses as follows:

$$
\begin{aligned}
y & =\beta^{\prime} x+\varepsilon, \\
z^{*} & =\alpha^{\prime} v+u, \\
\varepsilon, u & \sim N\left(0,0, \sigma_{\varepsilon}^{2}, \sigma_{u}^{2}, \rho\right) .
\end{aligned}
$$

As usual $z^{*}$ is unobserved. We observed the following:

$$
\begin{aligned}
z=0 & \text { if } z^{*} \leq 0, \\
=1 & \text { if } 0 \leq z^{*}<\mu, \\
=2 & \text { if } \mu \leq z^{*} .
\end{aligned}
$$

The $\mu$ is an unknown parameter to be estimated with $\alpha$.

$$
\begin{aligned}
E\left(y_{i} \mid x_{i}, \text { in sample }\right) & =E\left(y_{i} \mid x_{i}, z=1\right) \\
& =\beta^{\prime} x+\left(\rho \sigma_{\epsilon} \sigma_{u}\right)\left[\phi\left(\alpha^{\prime} w_{i}\right) / \Phi\left(\alpha^{\prime} w_{i}\right)\right] .
\end{aligned}
$$

Greene (1993) indicates that $\sigma_{u}$ cannot be estimated, so it is normalized to 1.

Then, in the second stage,

$$
\begin{aligned}
E\left(y_{i} \mid x_{i}, \text { in sample }\right) & =\beta^{\prime} x+\left(\rho \sigma_{\epsilon} 1\right)\left[\phi\left(\alpha^{\prime} w_{i}\right) / \Phi\left(\alpha^{\prime} w_{i}\right)\right] \\
& =\beta^{\prime} x+\theta \lambda,
\end{aligned}
$$

where $\theta=\left(\rho \sigma_{\epsilon}\right)$ and $\lambda=\left[\phi\left(\alpha^{\prime} w_{i}\right) / \Phi\left(\alpha^{\prime} w_{i}\right)\right]$.

Greene (1993) notes that the estimation of this model by a two step procedure follows the steps in Heckman (1979) and Greene (1981). ${ }^{3}$

The steps are:

1. Estimate the ordered probit by MLE using all observations.

2. Select the observations for the regression.

3. Estimated the primary equation by OLS including the correction term $E(\epsilon \mid z=j)$.

4. Correct the estimated asymptotic covariance matrix of the estimates.

\footnotetext{
${ }^{3}$ For a complete description of the ordered probit selection model, see Greene (1993) and LIMDEP User's Manual, 7th ed.
} 


\section{A Financial Model}

In the first stage, observations are classified into three categories according to the value of investments in China by Taiwanese firms. $Z$ is used to denote the category, here $Z=0,1$ or $Z=0,1,2 .{ }^{4}$ In the second stage, for each category, the corresponding probabilities derived from the first stage are applied for further regression analysis. In the first stage, what factors can identify which listed company in Taiwan has more incentive to invest in China is the focus. In the second stage, analysis of the impact of fundamentals on stock returns are conducted by transforming the probability derived from the first stage into the variables in the second stage regression model. The empirical result will be analyzed to find out whether there is any difference existing for the relation between stock returns and fundamental across company. In the $Z=0,1$ category, company that has no approved China-investment by ICMEA is set to be "0" and named as non-China-concept stock. On the other hand, company with approved China-investment is set to be "1" and named as China-concept stock. In order to explore the China-investment effect in depth, we further split the China-concept stocks into two groups based on the intensity of investment in China by Ordered Probit selection model. Hence, in the Ordered Probit model, for China-concept stock, company with approved China-investment amount less or large than the average of total China-investment amount is set to be "1" or "2" and named as moderatelevel China-concept stock or heavy-level China-concept stock respectively.

The financial model applied in this study is as follows:

First Stage:

$$
\begin{aligned}
Z_{i}= & a_{0}+a_{1} \mathrm{EXP}_{t-1}+a_{2} \mathrm{LABOR}_{t-1}+a_{3} \mathrm{AGE}_{t-1}+a_{4} \mathrm{DEBT}_{t-1} \\
& +a_{5} \mathrm{RE}_{t-1}+a_{6} \mathrm{SALE}_{t-1}+a_{7} \mathrm{PRO}_{t-1}+a_{8} \mathrm{NW}_{t-1}+u_{t},
\end{aligned}
$$

where

$Z$ means with China-investment or not; if the answer is yes then $Z=1$ or 2 , else $Z=0$;

$\mathrm{EXP}=$ Export ratio;

LABOR $=$ Degree of labor concentration (Total number of labor employed/ Total Asset);

AGE $=$ Company age;

DEBT $=$ Debt ratio (Long Term Debt/Equity);

\footnotetext{
"In the Probit Model, the dependent variable is assumed to be "binary" or "dichotomous", that is $Z=0,1$; but in the Ordered Probit Mode, the independent variable is assumed to be orderly classified, for example, $Z=0,1,2,3$.
} 
$\mathrm{RE}=$ Retained earning ratio (Retained Earning/Total Asset);

$\mathrm{SALE}=$ Sales growth rate;

$\mathrm{PRO}=$ Profit ratio;

$\mathrm{NW}=$ Net worth (Net worth per share/10).

Second Stage:

$R_{i t}=b_{0 i}+b_{1 i} \mathrm{BETA}_{t-1}+b_{2 i} \mathrm{EP}_{t-1}+b_{3 i} \mathrm{BM}_{t-1}+b_{4 i} \mathrm{CP}_{t-1}+b_{5 i} \mathrm{SIZE}_{t-1}+e_{t}$,

where

$R_{i t}=$ Annual stock returns in period $t ;$

$\mathrm{BETA}=$ Beta calculated by running a regression of stock returns on market returns, using 60 monthly returns prior to period $t$;

$\mathrm{EP}=$ The ratio of earnings to market value of common equity;

$\mathrm{BM}=$ The ratio of book value to market value of common equity;

$\mathrm{CP}=$ The ratio of cash flow (earnings + depreciation) to market value of common equity;

SIZE $=$ The market value of common equity.

\section{Empirical Results}

Tables 4 and 5 are empirical results in the first stage. In the first stage, results derived from Probit Model and that from Ordered Probit Model are very similar. RE is found to have significant positive impact on company's decisions for investment in China. According to the Pecking Order Hypothesis, ${ }^{5}$ when a company requires capital for specific purpose, internal financing would be the first choice for funding the required capital, external financing is considered only if internal financing is insufficient. EXP, AGE and NW have partial explanation power and the positive coefficient implies that the higher export ratio, company age or net worth, the more likely the firm will invest in China. If a company oriented in export business, the abundant export and overseas market experience would increase the possibility for investing in China. In reality, the observation that the majority of Taiwan listed companies with investment in China are export-oriented companies corroborates our empirical results. The variable LABOR, although with positive coefficient during the observation period, it is not significant

\footnotetext{
${ }^{5}$ Donaldson (1961) and Myers (1984) suggest that a firm's financing may have a pecking order. When a firm needs to finance its investment, it will use internal source of funds first, then issue secured debts, risky debts, hybrid securities, and lastly new common shares.
} 
Table 4. First stage result $(Z=0,1)$ - Probit model.

$$
\begin{aligned}
Z_{i}= & a_{0}+a_{1} \mathrm{EXP}_{t-1}+a_{2} \mathrm{LABOR}_{t-1}+a_{3} \mathrm{AGE}_{t-1}+a_{4} \mathrm{DEBT}_{t-1}+a_{5} \mathrm{RE}_{t-1} \\
& +a_{6} \mathrm{SALE}_{t-1}+a_{7} \mathrm{PRO}_{t-1}+a_{8} \mathrm{NW}_{t-1}+u_{t}
\end{aligned}
$$

$\mathrm{EXP}=$ Export ratio; LABOR $=$ Degree of labor concentration (Total number of labor employed/Total Asset); $\mathrm{AGE}=$ Company age; DEBT $=$ Debt ratio (Long Term Debt/Equity); RE = Retained earning ratio (Retained Earning/Total Asset); $\mathrm{SALE}=$ Sales growth rate; $\mathrm{PRO}=$ Profit ratio; $\mathrm{NW}=$ Net worth $($ Net worth per

\begin{tabular}{|c|c|c|c|c|c|c|}
\hline Period & 1993 & 1994 & 1995 & 1996 & 1997 & 1998 \\
\hline Constant & $\begin{array}{c}-0.764 \\
(-0.879)\end{array}$ & $\begin{array}{l}-0676 \\
\quad(-1.044)\end{array}$ & $\begin{array}{l}-0.912 \\
(-1.169)\end{array}$ & $\begin{array}{l}-0.837 \\
(-1.765)^{* *}\end{array}$ & $\begin{array}{c}-0.781 \\
(-1.212)\end{array}$ & $\begin{array}{c}-0.873 \\
(-0.976)\end{array}$ \\
\hline EXP & $\begin{array}{l}0.672 \\
(1.906)^{* *}\end{array}$ & $\begin{array}{c}0.443 \\
(1.529)\end{array}$ & $\begin{array}{l}0.311 \\
(1.869)^{* *}\end{array}$ & $\begin{array}{l}0.607 \\
(1.771)^{* *}\end{array}$ & $\begin{array}{l}0.721 \\
(1.731)^{* *}\end{array}$ & $\begin{array}{c}0.539 \\
(1.965)^{*}\end{array}$ \\
\hline LABOR & $\begin{array}{c}0.08 \\
(0.841)\end{array}$ & $\begin{array}{c}0.059 \\
(0.721)\end{array}$ & $\begin{array}{c}0.052 \\
(0.765)\end{array}$ & $\begin{array}{c}0.051 \\
(0.614)\end{array}$ & $\begin{array}{c}0.072 \\
(0.663)\end{array}$ & $\begin{array}{c}0.083 \\
(0.792)\end{array}$ \\
\hline AGE & $\begin{array}{c}0.016 \\
(1.303)\end{array}$ & $\begin{array}{l}0.018 \\
(1.610)\end{array}$ & $\begin{array}{l}0.021 \\
(1.776)^{* *}\end{array}$ & $\begin{array}{l}0.026 \\
(1.764)^{* *}\end{array}$ & $\begin{array}{c}0.023 \\
(1.492)\end{array}$ & $\begin{array}{c}0.019 \\
(1.231)\end{array}$ \\
\hline DEBT & $\begin{array}{c}0.376 \\
(0.512)\end{array}$ & $\begin{array}{c}-0.335 \\
(-0.361)\end{array}$ & $\begin{array}{l}-0.189 \\
(-0.112)\end{array}$ & $\begin{array}{c}0.119 \\
(0.126)\end{array}$ & $\begin{array}{c}0.314 \\
(0.412)\end{array}$ & $\begin{array}{c}0.216 \\
(0.391)\end{array}$ \\
\hline $\mathrm{RE}$ & $\begin{array}{l}2.036 \\
(1.784)^{* *}\end{array}$ & $\begin{array}{c}3.146 \\
(2.178)^{*}\end{array}$ & $\begin{array}{c}4.812 \\
(3.163)^{*}\end{array}$ & $\begin{array}{c}3.678 \\
(2.119)^{*}\end{array}$ & $\begin{array}{c}3.791 \\
(1.987)^{*}\end{array}$ & $\begin{array}{c}4.912 \\
(2.107)^{*}\end{array}$ \\
\hline SALE & $\begin{array}{c}0.316 \\
(0.697)\end{array}$ & $\begin{array}{c}0.218 \\
(0.612)\end{array}$ & $\begin{array}{c}-0.037 \\
(-0.217)\end{array}$ & $\begin{array}{c}0.255 \\
(0.378)\end{array}$ & $\begin{array}{c}-0.214 \\
(-0.576)\end{array}$ & $\begin{array}{c}0.368 \\
(0.701)\end{array}$ \\
\hline PRO & $\begin{array}{c}0.615 \\
(0.512)\end{array}$ & $\begin{array}{c}0.397 \\
(0.598)\end{array}$ & $\begin{array}{l}-0.752 \\
(-0.841)\end{array}$ & $\begin{array}{l}-0.216 \\
(-0.319)\end{array}$ & $\begin{array}{c}0.718 \\
(0.581)\end{array}$ & $\begin{array}{c}-0.398 \\
(-0.412)\end{array}$ \\
\hline NW & $\begin{array}{l}0.497 \\
(1.912)^{* *}\end{array}$ & $\begin{array}{c}0.513 \\
(1.121)\end{array}$ & $\begin{array}{c}0.368 \\
(1.027)\end{array}$ & $\begin{array}{c}0.412 \\
(0.978)\end{array}$ & $\begin{array}{l}0.435 \\
(1.798)^{* *}\end{array}$ & $\begin{array}{c}0.301 \\
(1.969)^{*}\end{array}$ \\
\hline
\end{tabular}
share/10).

$t$-value in parenthesis; ${ }^{*}$ significance level $=0.05 ;{ }^{* *}$ significance level $=0.10$.

during the observation period. ${ }^{6}$ For DEBT, SALE and PRO, their coefficients have inconsistent signs in different observation periods, hence they are insignificant factors for firms making China-investment decision. Moreover, we cannot conclude whether companies that are doing successful in Taiwan have greater incentive to invest in China or not, similarly for those companies that perform not well in Taiwan, do they have greater tendency to consider investing in China is also of question.

The results for second stage are in Tables 6-8. BETA is insignificant and its coefficient in each year is inconsistent in sign for both China-concept stock and non-China-concept stock. It is consistent with some previous literature. Under Probit Model, for non-China-concept stock $(Z=0)$, BM is the

\footnotetext{
${ }^{6}$ In other words, LABOR has positive impact on China-investment decision for Taiwan listed company but with no explanation power.
} 
Table 5. First stage result $(Z=0,1,2)$ - Ordered Probit model.

$$
\begin{aligned}
Z_{i}= & a_{0}+a_{1} \mathrm{EXP}_{t-1}+a_{2} \mathrm{LABOR}_{t-1}+a_{3} \mathrm{AGE}_{t-1}+a_{4} \mathrm{DEBT}_{t-1}+a_{5} \mathrm{RE}_{t-1} \\
& +a_{6} \mathrm{SALE}_{t-1}+a_{7} \mathrm{PRO}_{t-1} a_{8} \mathrm{NW}_{t-1}+u_{t}
\end{aligned}
$$

$\mathrm{EXP}=$ Export ratio; LABOR $=$ Degree of labor concentration (Total number of labor employed/Total Asset); AGE = Company age; DEBT = Debt ratio (Long Term Debt/Equity); RE = Retained earning ratio (Retained Earning/Total Asset); $\mathrm{SALE}=$ Sales growth rate; $\mathrm{PRO}=$ Profit ratio; $\mathrm{NW}=$ Net worth $($ Net worth per share/10).

\begin{tabular}{lcccccc}
\hline Period & 1993 & 1994 & 1995 & 1996 & 1997 & 1998 \\
\hline Constant & -0.416 & -0.661 & -0.714 & -0.812 & -0.762 & -0.896 \\
& $(-0.598)$ & $(-0.872)$ & $(-1.126)$ & $(-1.768)^{* *}$ & $(-1.421)$ & $(-0.981)$ \\
EXP & 0.619 & 0.597 & 0.586 & 0.814 & 0.793 & 0.678 \\
& $(1.745)^{* *}$ & $(1.598)$ & $(1.962)^{* *}$ & $(2.013)^{*}$ & $(1.936)^{* *}$ & $(1.971)^{*}$ \\
LABOR & 0.079 & 0.066 & 0.041 & 0.042 & 0.068 & 0.078 \\
& $(0.712)$ & $(0.519)$ & $(0.611)$ & $(0.317)$ & $(0.615)$ & $(1.403)$ \\
AGE & 0.019 & 0.014 & 0.016 & 0.021 & 0.025 & 0.017 \\
& $(1.219)$ & $(1.015)$ & $(1.765)^{* *}$ & $(1.792)^{* *}$ & $(1.231)$ & $(1.403)$ \\
DEBT & 0.405 & -0.223 & -0.187 & 0.206 & 0.298 & 0.261 \\
& $(0.553)$ & $(-0.387)$ & $(-0.164)$ & $(0.317)$ & $(0.395)$ & $(0.318)$ \\
RE & 2.768 & 3.126 & 4.891 & 3.601 & 3.584 & 4.365 \\
& $(1.765)^{* *}$ & $(2.146)^{*}$ & $(3.912)^{*}$ & $(2.126)^{*}$ & $(1.972)^{*}$ & $(2.001)^{*}$ \\
SALE & 0.416 & 0.311 & -0.161 & 0.266 & -0.314 & 0.372 \\
& $(0.602)$ & $(0.572)$ & $(0.318)$ & $(0.334)$ & $(-0.651)$ & $(0.698)$ \\
PRO & 0.368 & 0.419 & -0.846 & -0.196 & 0.726 & -0.314 \\
& $(0.219)$ & $(0.410)$ & $(-0.912)$ & $(-0.315)$ & $(0.612)$ & $(-0.393)$ \\
NW & 0.661 & 0.349 & 0.394 & 0.357 & 0.408 & 0.412 \\
& $(1.124)$ & $(0.912)$ & $(1.016)$ & $(0.947)$ & $(2.12)^{*}$ & $(1.768)^{* *}$ \\
\hline
\end{tabular}

$t$-value in parenthesis; ${ }^{*}$ significance level $=0.05 ;{ }^{* *}$ significance level $=0.10$.

most significant factor with positive coefficients. As for China-concept stock $(Z=1)$, the result is generally similar to that of non-China-concept stock but with a slight difference; BM is still significant although the degree is decreasing. ${ }^{7}$ In order to explore this difference more detail we apply Ordered Probit Model and the results are appealing. For non-China-concept stock $(Z=0)$ and moderate-level China-concept stock $(Z=1)$, the results are generally like that under Probit Model. However, as for heavy-level Chinaconcept stock $(Z=2)$, the explanatory power of BM is found to be attenuated. The only difference lies on the fact that the significant impact of BM on stock returns will depend on the underlying risk of that stock. In short, BM is the most significant variable and the positive coefficient of BM implies that $\mathrm{BM}$ has significant and positive impact on stock returns consistent with the

\footnotetext{
${ }^{7}$ Besides by comparing the coefficient, the unit change of BM for non-China-concept stock has greater impact on stock returns than that for China-concept stock.
} 
Table 6. Second stage result for Probit Model -2 groups-classification $(Z=0)$.

$$
R_{i t}=b_{0 i}+b_{1 i} \mathrm{BETA}_{t-1}+b_{2 i} \mathrm{EP}_{t-1}+b_{3 i} \mathrm{BM}_{t-1}+b_{4 i} \mathrm{CP}_{t-1}+b_{5 i} \mathrm{SIZE}_{t-1}+e_{t}
$$

$\mathrm{BETA}=$ Beta calculated by running a regression of stock returns on market returns; $\mathrm{EP}=$ The ratio of earnings to market value of equity; $\mathrm{BM}=$ The ratio of book value to market value of common equity; $\mathrm{CP}=$ The ratio of cash flow (earnings + depreciation) to market value of equity; $\mathrm{SIZE}=$ The market value of equity.

\begin{tabular}{lcccccc}
\hline Period & 1993 & 1994 & 1995 & 1996 & 1997 & 1998 \\
\hline Constant & 0.316 & -0.706 & -0.079 & 0.018 & 0.312 & 0.098 \\
& $(0.364)$ & $(-1.184)$ & $(-0.361)$ & $(0.046)$ & $(0.344)$ & $(0.113)$ \\
BETA & 0.051 & 0.138 & 0.011 & -0.116 & 0.212 & 0.198 \\
& $(0.367)$ & $(0.916)$ & $(0.116)$ & $(-1.489)$ & $(0.317)$ & $(0.167)$ \\
EP & -1.312 & -1.712 & -0.418 & 1.098 & 0.081 & -0.117 \\
& $(-1.216)$ & $(-1.531)$ & $(-0.736)$ & $(1.312)$ & $(0.172)$ & $(-0.341)$ \\
BM & 0.516 & 0.712 & 0.098 & 0.346 & 0.196 & 0.218 \\
& $(4.161)^{*}$ & $(5.126)^{*}$ & $(1.765)^{* *}$ & $(3.136)^{*}$ & $(2.316)^{*}$ & $(3.148)^{*}$ \\
CF & 1.121 & 0.316 & 0.942 & -0.031 & 1.372 & 0.914 \\
& $(1.314)$ & $(0.912)$ & $(0.812)$ & $(-0.394)$ & $(1.412)$ & $(0.736)$ \\
SIZE & -0.123 & 0.042 & -0.012 & -0.011 & 0.057 & 0.011 \\
& $(-0.391)$ & $(0.172)$ & $(-0.031)$ & $(-0.059)$ & $(0.131)$ & $(0.016)$ \\
\hline
\end{tabular}

$t$-value in the parenthesis; ${ }^{*}$ significance level $=0.05 ;{ }^{* *}$ significance level $=0.10$.

Table 7. Second stage result -2 -groups-classification $(Z=1)$.

$$
R_{i t}=b_{0 i}+b_{1 i} \mathrm{BETA}_{t-1}+b_{2 i} \mathrm{EP}_{t-1}+b_{3 i} \mathrm{BM}_{t-1}+b_{4 i} \mathrm{CP}_{t-1}+b_{5 i} \mathrm{SIZE}_{t-1}+e_{t}
$$

$\mathrm{BETA}=$ Beta calculated by running a regression of stock returns on market returns; $\mathrm{EP}=$ The ratio of earnings to market value of equity; $\mathrm{BM}=$ The ratio of book value to market value of common equity; $\mathrm{CP}=$ The ratio of cash flow (earnings + depreciation) to market value of equity; $\mathrm{SIZE}=$ The market value of equity.

\begin{tabular}{lcccccc}
\hline Period & 1993 & 1994 & 1995 & 1996 & 1997 & 1998 \\
\hline Constant & -0.113 & -0.063 & -0.113 & 0.615 & 2.131 & 0.111 \\
& $(-0.121)$ & $(-0.106)$ & $(-0.314)$ & $(0.768)^{* *}$ & $(1.418)$ & $(0.097)$ \\
BETA & 0.067 & 0.129 & 0.021 & -0.012 & -0.041 & 0.211 \\
& $(0.391)$ & $(0.897)$ & $(0.109)$ & $(-0.912)$ & $(-0.137)$ & $(0.309)$ \\
EP & 0.191 & -1.312 & -0.369 & 1.141 & 0.076 & -0.123 \\
& $(0.211)$ & $(-0.513)$ & $(-0.212)$ & $(0.594)$ & $(0.212)$ & $(-0.271)$ \\
BM & 0.419 & 0.694 & 0.098 & 0.317 & 0.182 & 0.163 \\
& $(1.754)^{* *}$ & $(2.169)^{*}$ & $(1.808)^{* *}$ & $(1.745)^{* *}$ & $(1.982)^{*}$ & $(1.967)^{*}$ \\
CF & 0.011 & 0.837 & 0.779 & 0.312 & 0.472 & 1.131 \\
& $(0.113)$ & $(0.319)$ & $(0.678)$ & $(0.912)$ & $(1.765)^{* *}$ & $(0.721)$ \\
SIZE & -0.006 & 0.031 & 0.021 & 1.212 & 0.046 & -0.442 \\
& $(-0.012)$ & $(0.168)$ & $(0.061)$ & $(1.748)^{* *}$ & $(0.011)$ & $(-0.317)$ \\
\hline
\end{tabular}

$t$-value in parenthesis; ${ }^{*}$ significance level $=0.05 ;{ }^{* *}$ significance level $=0.10$. 
Table 8. Second stage result - 3-groups-classification $(Z=0)$.

$$
R_{i t}=b_{0 i}+b_{1 i} \mathrm{BETA}_{t-1}+b_{2 i} \mathrm{EP}_{t-1}+b_{3 i} \mathrm{BM}_{t-1}+b_{4 i} \mathrm{CP}_{t-1}+b_{5 i} \mathrm{SIZE}_{t-1}+e_{t}
$$

BETA = Beta calculated by running a regression of stock returns on market returns; $\mathrm{EP}=$ The ratio of earnings to market value of equity; $\mathrm{BM}=$ The ratio of book value to market value of common equity; $\mathrm{CP}=$ The ratio of cash flow (earnings + depreciation) to market value of equity; SIZE = The market value of equity.

\begin{tabular}{lcccccc}
\hline Period & 1993 & 1994 & 1995 & 1996 & 1997 & 1998 \\
\hline Constant & 0.214 & -0.512 & -0.081 & 0.029 & 0.317 & -0.126 \\
& $(0.252)$ & $(-1.016)$ & $(-0.124)$ & $(0.048)$ & $(0.402)$ & $(-0.014)$ \\
BETA & 0.081 & 0.162 & 0.012 & -0.114 & 0.132 & 0.267 \\
& $(0.492)$ & $(0.763)$ & $(0.112)$ & $(-0.912)$ & $(0.369)$ & $(0.148)$ \\
EP & -1.212 & -1.634 & -0.346 & 1.112 & 0.026 & -0.214 \\
& $(-1.316)$ & $(-1.394)$ & $(-0.921)$ & $(1.463)$ & $(0.011)$ & $(-0.317)$ \\
BM & 0.591 & 0.816 & 0.496 & 0.673 & 0.841 & 0.578 \\
& $(4.916)^{*}$ & $(5.338)^{*}$ & $(1.709)^{* *}$ & $(3.481)^{*}$ & $(2.412)^{*}$ & $(3.012)^{*}$ \\
CF & 1.011 & 0.612 & -0.012 & 1.126 & 0.912 & 0.894 \\
& $(1.062)$ & $(1.216)$ & $(-0.021)$ & $(1.231)$ & $(0.721)$ & $(0.618)$ \\
SIZE & -0.036 & 0.011 & -0.008 & -0.014 & 0.021 & 0.016 \\
& $(-0.312)$ & $(0.106)$ & $(-0.001)$ & $(-0.042)$ & $(0.016)$ & $(0.011)$ \\
\hline
\end{tabular}

$t$-value in the parenthesis; ${ }^{*}$ significance level $=0.05 ;{ }^{* *}$ significance level $=0.10$.

results by Fama and French (1992). In non-China-concept stock, BM has reliable explanatory power on the dispersion of returns among company. However, it loses its explanatory power after we introduce the China-investment effect and the explanatory power deteriorates through time.

The explanatory power of EP is varied through time and across the category of company, besides the sign is also inconsistent. CF is insignificant under Probit Model; however under Ordered Probit Model, $\mathrm{CF}$ is significant for heavy-level China-concept stock. Therefore we postulate that the $\mathrm{CF}$ effect is existing for China-concept stock. As for non-China-concept stock, there is no size effect, however under Ordered Probit Model, for heavy-level China-concept stock, an opposite size effect is found, that is stocks with larger size perform comparatively better. One possible explanation is that the small China-concept stocks examined in this study tend to be more sensitive to changes in the economy and they are less likely to survive adverse economic conditions. Our economic interpretation of why small China-concept stocks on average are riskier is thus based on the characteristics of the marginal firms that cause them to react differently from the healthy firms to the same piece of macroeconomic news. 
Table 9. Second stage result - 3 -groups-classification $(Z=1)$.

$$
R_{i t}=b_{0 i}+b_{1 i} \mathrm{BETA}_{t-1}+b_{2 i} \mathrm{EP}_{t-1}+b_{3 i} \mathrm{BM}_{t-1}+b_{4 i} \mathrm{CP}_{t-1}+b_{5 i} \mathrm{SIZE}_{t-1}+e_{t}
$$

BETA = Beta calculated by running a regression of stock returns on market returns; $\mathrm{EP}=$ The ratio of earnings to market value of equity; $\mathrm{BM}=$ The ratio of book value to market value of common equity; $\mathrm{CP}=$ The ratio of cash flow (earnings + depreciation) to market value of equity; $\mathrm{SIZE}=$ The market value of equity.

\begin{tabular}{lcccccc}
\hline Period & 1993 & 1994 & 1995 & 1996 & 1997 & 1998 \\
\hline Constant & 0.179 & -0.469 & -0.012 & 0.016 & 0.712 & -0.218 \\
& $(0.218)$ & $(-0.912)$ & $(-0.097)$ & $(0.031)$ & $(1.112)$ & $(-0.071)$ \\
BETA & 0.091 & 0.112 & -0.019 & -0.061 & 0.211 & 0.167 \\
& $(0.381)$ & $(0.641)$ & $(-0.081)$ & $(-0.134)$ & $(0.309)$ & $(0.311)$ \\
EP & -1.721 & -1.112 & 0.019 & -1.326 & 0.031 & -0.198 \\
& $(-1.463)$ & $(-1.312)$ & $(0.021)$ & $(-1.212)$ & $(0.024)$ & $(-0.207)$ \\
BM & 0.586 & 0.626 & 0.396 & 0.372 & 0.612 & 0.501 \\
& $(2.914)^{*}$ & $(1.514)^{* *}$ & $(1.765)^{* *}$ & $(1.810)^{* *}$ & $(1.761)^{* *}$ & $(2.146)^{*}$ \\
CF & 0.916 & 1.272 & 0.848 & 1.146 & 1.362 & 0.948 \\
& $(0.612)$ & $(0.813)$ & $(0.612)$ & $(0.781)$ & $(1.765)^{* *}$ & $(0.635)$ \\
SIZE & -0.012 & 0.021 & 0.016 & -0.024 & 0.028 & -0.017 \\
& $(-0.126)$ & $(0.113)$ & $(0.002)$ & $(-0.216)$ & $(0.021)$ & $(-0.019)$ \\
\hline
\end{tabular}

$t$-value in parenthesis; ${ }^{*}$ significance level $=0.05 ;{ }^{* *}$ significance level $=0.10$.

Table 10. Second stage result -3 -groups-classification $(Z=2)$.

$$
R_{i t}=b_{0 i}+b_{1 i} \mathrm{BETA}_{t-1}+b_{2 i} \mathrm{EP}_{t-1}+b_{3 i} \mathrm{BM}_{t-1}+b_{4 i} \mathrm{CP}_{t-1}+b_{5 i} \mathrm{SIZE}_{t-1}+e_{t}
$$

$\mathrm{BETA}=$ Beta calculated by running a regression of stock returns on market returns; $\mathrm{EP}=$ The ratio of earnings to market value of equity; $\mathrm{BM}=$ The ratio of book value to market value of common equity; $\mathrm{CP}=$ The ratio of cash flow (earnings + depreciation) to market value of equity; SIZE = The market value of equity.

\begin{tabular}{lcccccc}
\hline Period & 1993 & 1994 & 1995 & 1996 & 1997 & 1998 \\
\hline Constant & 1.267 & -1.471 & -0.091 & 2.017 & 3.412 & -1.014 \\
& $(0.481)$ & $(-1.021)$ & $(-0.113)$ & $(1.137)$ & $(1.447)$ & $(-0.912)$ \\
BETA & -0.167 & 0.181 & 0.141 & 0.128 & -0.137 & -0.212 \\
& $(-0.316)$ & $(0.398)$ & $(1.136)$ & $(0.216)$ & $(-0.281)$ & $(-0.461)$ \\
EP & -1.214 & -3.126 & -1.107 & 2.964 & 1.364 & 1.892 \\
& $(-0.311)$ & $(-1.213)$ & $(-0.523)$ & $(0.612)$ & $(0.367)$ & $(0.646)$ \\
BM & 0.162 & 0.216 & 0.016 & 0.192 & 0.462 & 0.492 \\
& $(0.816)$ & $(1.014)$ & $(1.751)^{* *}$ & $(0.691)$ & $(0.491)$ & $(1.789)^{* *}$ \\
CF & 1.287 & 4.021 & 0.416 & 2.127 & 2.416 & 0.976 \\
& $(0.319)$ & $(1.804)^{* *}$ & $(0.316)$ & $(0.573)$ & $(1.772)^{* *}$ & $(1.765)^{* *}$ \\
SIZE & 0.031 & 0.087 & 0.048 & 0.212 & 0.267 & 0.092 \\
& $(0.192)$ & $(0.312)$ & $(0.912)$ & $(1.765)^{* *}$ & $(1.137)$ & $(1.765)^{* *}$ \\
\hline
\end{tabular}

$t$-value in parenthesis; ${ }^{*}$ significance level $=0.05 ;{ }^{* *}$ significance level $=0.10$. 


\section{Conclusions}

This paper evaluates the performance of fundamental factors in capturing the systematic co-variation in stock returns; we examine the risk differences that lead firms with real investments in China or not. Due to the rising popularity of China-concept stocks, this paper studies Taiwan stock market from another angle to find out the impact that China-investment has on the explanation power of fundamentals. The objective is investigating the impact of China investment policy on the stock returns and market fundamentals, the empirical results and main findings achieved by this study can be summarized as follows. First, the higher the retained earning to capital ratio, the higher the export ratio or the longer the years of establishment, the higher the probability a firm will invest in China. Second, the impact that fundamental variables have on stock returns has a slight difference between China-concept stocks and non-China-concept stocks but the difference will be highlighted more under Ordered Probit Model. Finally, BM is found to capture variations in stock returns in Taiwan stock market for non-China-concept stocks, for China-concept stock the explanatory power is not so significant and varied through time; besides explanatory power deteriorates through the intensification of investment in China. Therefore, when analyzing the impact of company fundamentals on returns of China-concept stocks, it is worthwhile to apply different proxy and further analysis of the corresponding results can assure a more accurate result.

In short, our tests do not support the central prediction of the Sharp-Lintner-Blank model, that average stock returns are positive related to market BETA. The unit change of coefficient of BM for non-China-concept stock has greater impact on stock returns than that for China-concept stock. The difference between China-concept stock and nonChina-concept stock, may be due to differences in the patterns of their underlying cash flows. In our context, if we were to restrict attention to the normal model without introducing the China-investment effect, we would be led to conclude, as earlier studies have, that BM has significant and positive impact on stock returns, hence is the most important factor. Yet this inference would be attenuated when China-investment effect is introduced. Our findings suggest that, in general, such statistical inferences should be made with caution since the correct specification is unknown. Our results imply that the list of fundamental variables employed in this paper is not exhaustive for Chinaconcept stock. For example, the results indicate that large companies significantly outperform small companies for China-concept stock. Examining the relations between the returns and economic variables that measure variation 
in business conditions might help expose the nature of the economic risks faced by China-concept stock. Although BM has been shown to be a measure of the return prospects of stocks, there is evidence that its explanatory power deteriorated through the increase of investment intensity in China. The performance of SIZE is more dependent on the particular type of company and time period used. While previous studies document earnings effect, we find no evidence of a strong positive effect. The noise in reported earnings related to Taiwan accounting standards may also help to explain why BM has such a strong influence. Firms with large capital investments accordingly tend to have substantially understated earnings. As a result, a variable such as earnings yield might be of limited use in cross-company (China-concept versus non-China-concept stocks) evaluations compared with broader measures such as cash flow yield. It is also understandable that the cash flow yield variable has higher predictive power than earnings yield, in light of the distortions in the earnings of China-concept stocks.

Our finding raises the possibility that earlier studies linking stock return in Taiwan to fundamental variables should be interpreted with caution; potentially important explanatory variables may have been omitted. The mis-assessment of risk has the potential to explain why small firms, high book-to-market ratio firms do not display large returns for China-concept stock. Possibly the poor showing of the fundamental factors may be due to measurement errors in the estimated sensitivities. We argue that there are important economic reasons why China-concept stock and non-Chinaconcept stock have different risk and return characteristics. The risk of China-concept stocks are not likely to be captured by a market index heavily weighted toward non-China-concept stocks. The implication of this study might be that some particular types of stock have abnormal market behavior, therefore leading changes to the impact of fundamentals on stock returns. Therefore the contribution of this paper lies on the separation of observation in accordance with specified clarification standards. Results of this study also point the importance of further research on the impact of fundamentals on stock returns. If our results are more than chance, they have practical implications for portfolio formation and performance evaluation by investors whose primary concern is long-term return or focusing-group performance.

\section{Acknowledgment}

Sponsored by the National Science Council of the Republic of China, NSC89-2416-H-048. 


\section{References}

Ball, R (1978). Anomalies in relationships between securities' yields-surrogates. Journal of Financial Economics, 6, 103-126.

Banz, S (1981). The relationship between securities' yield and yield-surrogates. Journal of Financial Economics, 9, 3-18.

Basu, S (1983). The relationship between earnings' yield, market value and return for NYSE common stock. Journal of Financial Economics, 12, 129-156.

Basu, S (1977). Investment performance of common stocks in relation to their priceearnings ratios: A test of the efficient market hypothesis. Journal of Finance, 663-682.

Beaver, W and D Morse (1978). What determines price-earnings ratios? Financial Analysts Journal, July-August, 65-74.

Breen, W (1968). Low price-earnings ratios and industry relatives. Financial Analysts Journal, July-August, 125-127.

Brown, SL (1978). Earnings changes, stock prices, and market efficiency. Journal of Finance, 17-28.

Campbell, JY and R Shiller (1988). Stock prices, earnings and expected dividends. Journal of Finance, 43, 661-676.

Chan, KC and N Chan (1991). Structural and return characteristics of small and large firms. Journal of Finance, 46, 1467-1484.

Chan, KC (1988). On the contrarian investment strategy. Journal of Business, $147-163$.

Chan, KC, J Karceski and J Lakonishok (1998). The risk and return from factors. Journal of Financial \& Quantitative Analysis, 159-188.

Chan, LKC, Y Hamao and J Lakonishik (1993). Can fundamentals predict Japanese stock returns. Financial Analysts Journal, 63-69.

Chan, LKC, Y Hamao and J Lakonishok (1991). Fundamentals and stock returns in Japan. Journal of Finance, December, 1739-1764.

Dennis, P, SB Perfect, KN Snow and KW Wiles (1995). The effects of rebalancing on size and book-to-market ratio portfolio returns. Financial Analysts Journal, May-June, 47-57.

Fama, EF and KR French (1992). The cross-section of expected stock returns. Journal of Finance, June, 427-465.

Fama, EF (1991). Efficient capital markets: II. Journal of Finance, 46, 1575-1617.

Fama, EF and KR French (1995). Size and book-to-market factors in earnings and returns. Journal of Finance, March, 131-155.

Goodman, DA and JW Peavy (1985). The risk universal nature of the P/E effect. Journal of Portfolio Management, Summer, 14-16.

Greene, WH (1992). LIMDEP-User's Manual and Reference Guide. New York: Econometric Software, Inc.

Greene, WH (1990). Econometric Analysis. New York: Macmillian.

Harris, RS and FC Marston (1994). Value versus growth stocks: Book-to-market, growth and beta. Financial Analysts Journal, September-October, 18-24.

Keim, DB (1990). A new look at the effects of firm size and E/P ratio on stock returns. Financial Analysts Journal, March-April, 56-67. 
Loughran, T (1997). Book-to-market across firm size, exchange \& seasonality: Is there an effect? Journal of Financial \& Quantitative Analysis, 32, 249-268. McWilliams, JD (1966). Prices, earnings and P/E ratios. Financial Analyst Journal, May-June, 137-142.

Nicholson, SF (1960). Price-earnings ratios. Financial Analysts Journal, July-August, 43-45.

Reinganum, MR (1981). Misspecification of capital asset pricing: Empirical anomalies based on earnings' yields and market values. Journal of Financial Economics, 19-46.

Roll, R (1981). A possible explanation of the small firm effect. Journal of Finance, 879-888.

Rosenberg, B, K Reid and R Lanstein (1985). Persuasive evidence on market inefficiency. Journal of Portfolio Management, 9-16.

Stattman, D (1988). Book values and stock returns. The Chicago MBA: A Journal of Selected Papers, 4, 25-45.

Yang, CC (1996). The relations between stock returns and firm fundamentals for firms selecting alternative external financing. Journal of Financial Studies, 2(2), 99-133. 
Copyright of Review of Pacific Basin Financial Markets \& Policies is the property of World Scientific Publishing Company and its content may not be copied or emailed to multiple sites or posted to a listserv without the copyright holder's express written permission. However, users may print, download, or email articles for individual use. 